\title{
RIEGL, WORRINGER ȘI „LECTURILE INFIDELE” ALE STILULUI ÎN ESTETICA LUI LUCIAN BLAGA
}

\section{IOANA PAVEL}

\section{Universitatea Babeș-Bolyai, Cluj-Napoca}

Abstract: This study aims to illustrate the original assimilation of style in Lucian Blaga's philosophy. His concept (or idea) of style is developed from the Philosophy of style to the Trilogies, being tributary to the idealistic philosophy and to the Vienna School of Art History. Of course, this inspiration does not represent an innocent reading of different German studies. By invoking Alois Riegl's "will of art" or Wilhelm Worringer's dichotomy between "abstraction" and "empathy", Blaga identifies the weaknesses from their work. Without giving up the contradictory and vulnerable aspects, he integrates and assimilates them in his philosophical and aesthetic system.

Keywords: Lucian Blaga's philosophy, Alois Riegl, Wilhelm Worringer, style, philosophical and aesthetic system.

\section{Premise: recuperări comparatiste}

Consacrate ca sistem filozofic unitar și invocate de cele mai multe ori clișeic în discuțiile asupra operei poetice a lui Lucian Blaga, trilogiile, dar și și textele eseistice anterioare lor sunt tributare $-s$-a observat adesea ideilor din spațiul cultural german. Măsura în care gândirea lui Blaga se revendică de la aceste concepții și studii (citite în original, să nu uităm, cu preocupare asupra metodelor de cercetare sau de abordare a esteticului în epocă) nu prea intră în atenția abordărilor comparatiste recente, deși, paradoxal, acestea insistă asupra valorificării ideilor în circulația lor internațională în defavoarea identificării lor „locale”. Astfel de exerciții există, e adevărat (a se vedea Dumitru Micu, Estetica lui Lucian Blaga, 1970, Michael S. Jones, Metafizica religiei, 2014 sau, și mai recent, CornelFlorin Moraru, Atitudinea estetică în filosofia artei. Aplicații asupra esteticii lui Lucian Blaga și Maurice Merleau-Ponty, 2018), dar ele nu conturează, în adevărata lui complexitate, profilul individual al lui Blaga dat de formația 
sa intelectuală germanofilă, despre care notează Crohmălniceanu: „Într-o vreme când mai toţi literaţii noştri se aflau sub vraja lui Baudelaire, Rimbaud, Mallarmé, Valéry sau Jammes, idolii săi erau Goethe, Rilke, Ştefan George, Mombert şi Trakl. Pe tărâm speculativ, iarăşi, îl atrăgeau ideile unor Nietzsche şi Klages, Spengler şi Veihinger, Woringer şi Riegl, preocupările «Lebensphilosophiei» şi «Gestaltismului», «fenomenele originare» şi problemele de morfologia culturii." (Crohmălniceanu, 1974, 196-197).

Desigur, raportarea lui Blaga la filozofia europeană a epocii sale nu înseamnă preluarea și simpla integrare a ideilor în construcția unei viziuni despre artă, ci poate implica și atitudini polemice faţă de studii care fac carieră în spațiul german. E cazul, spre exemplu, lui Wölfflin și al „categoriilor viziunii” pe care le propune în raport cu translația de la Renaștere la arta barocă (în Principii fundamentale ale istoriei artei), pe care le-am investigat cu altă ocazie (Pavel, 2018). Un astfel de exercițiu propune și studiul de față, prin interesul acordat construcției ideii, respectiv a conceptului de stil în gândirea blagiană (din Filozofia stilului, inițial, rafinată ulterior în Trilogii), raportându-se la „originile” Alois Riegl și Wilhelm Worringer.

\section{Artă și valoare, artă și știință}

Apusul romantismului în spațiul european, la finalul secolului al XIX-lea, aduce o mutație nu doar la nivelul artei, ci și la acela al teoretizărilor ei. În consecinţă, accentele idealismului german se deplasează către abordarea metodologică bazată pe științificitate (idee observată și de Blaga, în Artă și valoare - Blaga, 1939, 53), dată de cooperarea unor discipline complementare (psihologie, sociologie etc.). Mai mult decât atât, inclusiv în zona restrânsă a artisticului se face distincția între estetică (interesată de categoria frumosului), respectiv știința artei (al cărei obiect e arta, indiferent de manifestările ori mutațiile ei). Strict în privința spațiului cultural german, notele dominante ale acestor dinamici sunt date de impactul Școlii Vieneze și cel al formalismului figurativ, care mută accentul dinspre subiectivitatea geniului romantic înspre abordarea obiectivată a istoriei artei. În acest sens, arta nu mai e produsul unui subiect, ci al unei întregi epoci (care își manifestă „voința-de-artă”, după cum se va vedea), iar istoria artei devine istorie a stilurilor, nu a operelor artistice, dizolvând, astfel, ideea unui canon estetic imuabil.

În linii generale, stilul trimite la categoriile formale ale unei opere, reunind tehnici, metode, limbaj, manifestări exterioare / materiale 
care fac oficiile conținutului sau ale mesajului transmis către publicul receptor. O asemenea definiție „convențională” însă ar putea fi, probabil, una dintre concluziile unei (nescrise încă) monografii a ideii de stil, care ar marca mai degrabă tendința structuralistă de analiză a unei opere de artă. Pentru autorii discutaţi, stilul își transcende limitele pur formale, contribuind la caracterizarea orizontului (nu doar de așteptare al) unei epoci, ajungând până la asumarea ontologicului, în cazul lui Blaga. După Micu, viziunea asupra stilului în estetica lui Blaga se datorează în mare măsură și ideii nietzcheene de stil cultural, aşa încât stilul „nu definește, în viziunea blagiană, doar operele de artă, ci ansamblul creațiilor spirituale. Prin stil, arta iese oarecum din ea însăși, spre a particulariza la cultura unei societăți, unui popor, unei epoci." (Micu, 1970, 16).

\section{Stilul - de la categorie supraindividuală la categorie ontologică}

Interdependența dintre stil şi perspectiva asupra istoriei artei devine programatică la începutul secolului al XX-lea. In viziunea lui Riegl din 1902 (articolul O nouă istorie a artei), abordarea diacronică a esteticului ca disciplină științifică are datoria de a încadra opera individuală într-un concept larg al stilului (Demetrescu, 1998, 9), care devine, prin urmare, o categorie supraindividuală, ceea ce îl îndreptățește pe istoricul artei să discute despre stilul unei epoci, nu despre stilul unei opere. Din nou, acest stil al epocii e rezultanta voinței-de-artă ca proces: „Kunstwollen nu înseamnă voință artistică, pentru că nu este formulat Kunstwille, ci mai degrabă actul de a voi arta, indicând adică un proces, exprimat prin verbul wollen, nu prin substantivul Wille." (Demetrescu, 1998, 29).

$\mathrm{Cu}$ alte cuvinte, stilul reflectă intenționalitățile și refulările transpuse artistic, în „cod” psihanalitic, adică toate manifestările figurative aflate sub tutela artei, indiferent de receptarea lor. Polemizând cu materialismul lui Gottfried Semper, Riegl studiază modelul covoarelor orientale și demonstrează, prin acest exemplu, continuitatea stilistică a artei pe parcursul mileniilor. Argumentul continuității e susținut și de exemplul artelor decorative, ornamentica, deși discreditată, poate explica mecanisme stilistice ale altor epoci, întrucât „dublarea ş,i afrontarea simetrică a figurilor de-a lungul unei axe mediane poate fi explicată prin originea sa în tehnica textilă a țesutului artistic" (Riegl, 1998, 47).

Mai mult decât această idee sau supoziție a continuității, stilul geometric pe care se bazează ornamentica implică și argumentul unității stilistice: „legile matematice ale simetriei și ritmului, ale căror exemple pot fi considerate motivele simple ale stilului geometric, trebuie să fie aceleași 
pe tot globul, cu mici excepții” (Riegl, 1998, 48). Până la urmă, simetria ca axiomă configurativă definitorie a stilului geometric reprezintă dovada aceleiași unități stilistice: „Simțul artistic naiv al perioadelor timpurii pretindea mai presus de orice respectarea simetriei chiar și în reproducerea obiectelor naturale. [...] Trecerea de la stilizarea epocii arhaice la realismul modern nu s-a făcut însă dintr-o dată." (Riegl, 1998, 52). La popoarele așazis primitive, această unitate stilistică se constituie, de fapt, prin apariția spontană și simultană a stilului geometric: ,stilul geometric nu a apărut într-un singur punct al globului, răspândindu-se apoi pretutindeni, ci a apărut spontan dacă nu la toate, cel puțin la majoritatea popoarelor la care întâlnim folosirea lui. Stilul geometric a apărut spontan pe suprafața terestră: este prima teză pertinentă valabilă azi pentru acest stil.” (Riegl, 1998, 60).

Această supraindividualitate a stilului îi permite lui Riegl să observe, în diacronia artei, o mișcare continuă de epoci văzute obiectiv în succesiunea lor, fără judecăți de natură devalorizantă. Tocmai de aceea, aşa-numitele perioade „decadente” sunt, în realitate, stiluri greșit înțelese, ceea ce îi permite să recupereze și să revalorizeze epoca artei romane târzii și arta barocului. Aparenta lor „decadență” e amprenta dată de receptarea prezentului asupra unor fenomene estetice ale trecutului, drept care analiza corectă e cea de ordin contextual, care caută înțelesul relației dintre arta și filozofia unei epoci (Riegl, 1998, 140). Atitudinea e observabilă și în raportarea barocului la atmosfera secolului al XVII-lea în lectura (la fel de) "contextuală” a lui Blaga, care lansează și conceptul de „consens stilistic”, definit prin „rezultatul unor tendințe spirituale profunde, inconștiente, ce stau la temeiul tuturor manifestărilor spirituale dintr-un anume timp și spațiu istoric" (Blaga, 1983, 178).

În estetica lui Lucian Blaga, riegliana voință-de-artă se transformă întrun concept incluziv mai larg, și anume cel de "năzuință formativă", care variază de la o epocă la alta și care are în centru o valoare „pe care o realizează în materialul plastic al simțurilor și nu numai în acesta, ci în toate plăsmuirile conștiinței omenești, în cele teoretice, morale, religioase, sociale, artistice" (Blaga, 1924, 44). Puse în contrast, voința-de-artă variază diacronic și se rezumă la artă, în timp ce năzuința formativă stă la baza „tuturor creațiunilor posibile ale geniului omenesc dintr-un anumit timp și loc" (Blaga, 1924, 44).

Particularizând această năzuință formativă la nivelul stilurilor fundamentale (individualul, tipicul, absolutul), Blaga enunță și o teorie a influenței stilurilor (fără a o dezvolta și argumenta prea mult): „De câte ori 
observăm un stil care nu pătrunde toate ramurile creatoare ale spiritului, avem de a face nu cu ecoul unei năzuințe formative de baștină, ci cu un împrumut luat din afară ca program de realizat - deci cu o influență culturală." (Blaga, 1924, 58).

În mod evident, statutul supracategorial al stilului e păstrat și în viziunea blagiană: „stilul e un fenomen dominant al culturii umane și intră într-un chip sau altul în însăşi definiția ei [...] omul, manifestânduse creator, n-o poate face altfel decât în cadrul stilistic [...] Stilul e ca un jug suprem, în robia căruia trăim, dar pe care nu-l simțim decât arareori ca atare." (Blaga, 1985, 70). Cu alte cuvinte, supraindividualitatea stilistică (care a transgresat limitările formei) se transformă într-un statut ontologic, stilul devenind categorie ontologică.

\section{Stilul între abstracție și intropatie}

Recunoscând descendența ideilor sale din teoriile propuse de Riegl, Worringer lansează celebra dihotomie din(tre) Abstracție și intropatie (1908), cele două concepte fiind polii teoretici în jurul cărora se construiește o filozofie a artei bazată pe scheme antitetice, în continuarea antinomiilor rațiunii pure (Kant) ori a dialecticilor naiv-sentimental (Schiller), apolinic-dionisiac (Nietszche), apolinic-faustic (Spengler) etc. (Ianoși, 1970, XX). Mai mult, cele două concepte refac un traseu care evidențiază psihologia stilului, tot în perspectivă diacronică, psihologie care trece dincolo de limitele psihicului, în cazul lui Blaga, sondând pulsiunile inconstientului transpuse în forme artistice.

Revenind la dihotomia worringeriană, intropatia (concept preluat de la Th. Lipps) definește arta din perspectiva subiectului care o contemplă, însă ea rezolvă doar parțial problemele ridicate de istoria artei (Worringer, 1970, 22-23), drept care îi opune acesteia instinctul de abstracție: „Așa cum instinctul de intropatie, ca premisă a trăirii estetice, își găsește satisfacția în frumusețea organicului, tot așa instinctul de abstracție își află frumusețea sa în anorganicul care neagă viața." (Worringer, 1970, 23). Cele două concepte ar defini, până la urmă, starea psihică reflectată în și prin artă: „În timp ce instinctul de intropatie e condiționat de o relație de încredere panteistă fericită între om și fenomenele lumii exterioare, instinctul de abstractizare este consecința unei mari neliniști a omului, datorită fenomenelor lumii exterioare și corespunde din punct de vedere relativ unui colorit puternic transcendental al tuturor reprezentărilor. Această stare am dori să o definim ca o imensă teamă spirituală față de spațiu." (Worringer, 1970, 32). 
Simplificând, voința-de-artă se definește prin doi poli, abstracția și intropatia, care au, la rândul lor două efecte: naturalismul (diferit de imitația naturii), respectiv (și în această ordine) stilul (Worringer, 1970, 40). De obicei, abstracția și intropatia sunt concepte care se exclud, istoria artei relevând dezbaterea lor continuă (Worringer, 1970, 54) și devenind marcator psihologic al identității etnice: „datorită predispoziției sale înnăscute, fiecare popor este înclinat mai mult într-o parte sau alta; stabilind dacă în arta sa predomină instinctul de abstracție sau cel de intropatie, obținem în același timp o importantă caracteristică psihologică” (Worringer, 1970, 55). Cu toată această inserție psihologică a abordării, care ar trebui să conducă înspre o obiectivizare a abordării esteticului, stilul se „măsoară”, paradoxal, prin nevoia psihică generatoare de stil ca... „fericire”: „Fiecare stil a reprezentat - pentru umanitatea care l-a creat, pornind de la nevoile sale psihice - cea mai mare fericire. Aceasta trebuie să devină dogma supremă a oricărei cercetări obiective a istoriei artelor." (Worringer, 1970, 30). Rămâne de văzut în ce măsură valoarea estetică drept valoare „de fericire” e asociabilă cu abstracția ca expresie a neliniștilor unei epoci.

Comentând această dihotomie, Blaga notează faptul că aceste ramificații ale esteticului articulează opoziția și interferența deopotrivă dintre estetic și intelectual (aparținând cunoaşterii, așadar): „1. Simpatia [adică intropatia - n.n.] nu e de natură specific estetică. 2. Abstracțiunea nu e de natură specific «intelectuală» (cognoscivă). 3. Simpatia e adeseori cognoscivă, abstracțiunea adeseori estetică.” (Blaga, 1924, 31-32). Perspectiva de tinerețe (din Filozofia stilului, așadar) intuiește „consensul stilistic" pe care îl va conceptualiza mai târziu.

Această gândire dialectică se „maturizează” în cazul esteticii lui Blaga până la transgresarea graniței psihic/psihologic către psihanalitic. Mai mult decât o categorie ontologică, așa cum am observat anterior, stilul e reflectarea „stilistică” a inconștientului: „stilul, al unei opere de artă de pildă, se întipărește, ce-i drept, operei concomitent cu crearea ei; dar acest efect n-are loc în cadrul unei intenționalități conștiente. Oricât de intențională sub unele aspecte, opera de artă e, tocmai prin această pecete stilistică a ei mai adâncă, un produs al unor factori în ultimă analiză inconștienți [s.a. - L.B.]” (Blaga, 1985, 77). Tocmai de aceea, etapa trilogiilor e și momentul de depăşire a abordării stilului din punct de vedere fenomenologic și morfologic (Spengler și Frobenius), integrând elementele de „conținut” sub tutela aceluiași stil: „fenomenul stil constă nu numai din "forme», ci și din alte elemente precum: orizonturi, accente 
și atitudini” (Blaga, 1985, 80).

$\mathrm{Cu}$ rol esențial în configurarea stilului, inconștientul nu e asociat în estetica blagiană unei dezordini refulatoare de ordin freudian, ci reprezintă, dimpotrivă, o realitate psihică de o „pronunțată complicație interioară, de-o mare diversitate de elemente și structuri, organizată potrivit unei ordine imanente, rotunjită în rosturile sale, cu centrul de echilibru în sine însăși, adică relativ sieși suficientă” (Blaga, 1985, 85). Tot în acest cadru se configurează și „matricea stilistică”, nimic altceva decât „un complex inconștient” compus dintr-o serie de determinante (orizontul spaţial, temporal, accente axiologice, anabasicul / catabasicul și, nu în ultimul rând, năzuința formativă) (Blaga, 1985, 179).

Stilul - pentru Blaga - nu e categorie absolută, ci mai degrabă produsul matricii stilistice alcătuite din „categorii abisale, discontinue, dar sinergic și arhitectonic combinate” (Blaga, 1985, 438). Dincolo de acest transfer de la supraindividual la ontologic și, mai departe, la inconștient (deci, psihanalitic), Blaga demontează ideea de unitate stilistică absolută, pledând mai degrabă pentru caracterul elastic al stilului: „Unitatea de stil nu e un ce absolut. Stilul, fiind întemeiat pe o combinație arhitectonică de factori discontinui, manifestă o remarcabilă elasticitate.” (Blaga, 1985, 440). Cu alte cuvinte, contradicția pe care o regăsește în teoria unității stilistice e integrată la nivelul superior al elasticității stilului, tendință de asimilare teoretică recurentă în sistemul filozofic blagian.

\section{Naturalism, realism și stil}

Indivizibil legat de stil, naturalismul e una dintre problematicile lansate de Riegl și aflate în centrul preocupărilor lui Worringer și Blaga în materie de filozofia artei. Fără să insiste asupra imitației realității empirice, Riegl sesizează, în studiul dedicat artei barocului, deplasarea accentului de la un mimetism „obiectiv” la unul „subiectiv”, conștient de modificările pe care le operează asupra naturii: „Așa cum reiese din denumire, adepții acestui stil vor să picteze natura așa cum este, adică așa cum au văzut-o sau așa cum au crezut că o văd. [...] Apare astfel pentru prima dată recunoașterea deschisă a unui subiectivism conștient, un subiectivism optic" (Riegl, 1998, 246). Totodată, Riegl observă şi evoluția „gramaticală” a artelor în corelație cu viziunea despre lume, ceea ce transformă arta într-o corectare a naturii, fie prin frumusețe fizică (Riegl, 1998, 264), fie prin frumusețe spirituală (Riegl, 1998, 272), întrucât, până la urmă, „,[o]pera de artă umană este o competiție cu natura.” (Riegl, 1998, 314).

În privința lui Worringer, așa cum am văzut, naturalismul e produsul 
artistic al intropatiei și nu se confundă cu imitația fidelă a naturii. În plus, această tendință e specifică Antichității și Renașterii, definindu-se prin ,autenticitatea organică; dar nu pentru că s-a urmărit să se reprezinte aidoma unui obiect al naturii în corporalitatea sa, nu pentru că s-a urmărit să se dea iluzia viului, ci pentru că sentimentul față de frumusețea formei organic-autentice fusese trezit și pentru că se căuta satisfacerea acestui sentiment care stăpânea voința artistică absolută. Se năzuia spre fericirea provocată de viul organic, nu spre cea produsă de viul autentic." (Worringer, 1970, 41).

În Filozofia stilului, Blaga comentează, pe urmele lui Max Deri, cele trei tendințe fundamentale care generează stilurile (individualul, tipicul, absolutul): naturalismul, idealismul și expresionismul. Deși teoriile lui Worringer sunt invocate și (contra)argumentate, Blaga preferă, de această dată, o formulă aproape hegeliană de evoluție, considerând naturalismul „reproducerea în artă a unui lucru cât mai fidel după natură” (Blaga, 1924, 41) (adică, în termenii lui Worringer, imitație a naturii, nicidecum naturalism), idealismul - tendința de a corecta natura care nemulțumește (Blaga, 1924, 42), iar expresionismul - tendința spre exagerare și accentuare în ordinea obținerii expresivității maxime (Blaga, 1924, 42). Worringeriana schemă dialectică e supusă unei revizuiri care adaugă expresionismul ca deformare intenționată în căutarea expresivității, ceea ce rezolvă - în sistemul estetic blagian - eterna polemică între imitația naturii sau refuzul ei în reprezentarea artistică.

\section{În loc de concluzii: pentru o ,noologie abisală”}

Practicând mai mult o configurare sistemică decât o deconstrucție, Blaga nu demontează idei și concepte fără a le înlocui sau fără a le integra într-o viziune mai largă asupra fenomenelor pe care le discută. În acest caz, interferențele ideilor despre stil din spațiul cultural german sunt dovada „lecturilor infidele” ale textelor care fac carieră în Occident, nu în sensul unor interpretări parțiale ori subversive, ci în acela al asimilării originale. Voința-de-artă se transformă în năzuință formativă, iar stilul supraindividual e „travestit” în oglinzile psihanalizei pentru a face posibilă asumarea (in)conștientă a spiritului.

Tocmai de aceea, coordonatele stilistice ale diferitelor popoare pot fi considerate „funcții modelatoare” ale spiritului inconștient, ceea ce depășește stadiul psihologiei, dar permite definirea ei ca „noologie abisală” (Blaga, 1987, 56). De fapt, (și) în această logică se poate vedea tendința recurentă a lui Blaga de a instrumenta referințele anterioare nu în sensul 
subminării lor polemice, ci în acela al proiectării lor într-un sistem filozofic suficient de articulat încât să le asimileze. Contradicțiile identificate în teoriile filozofice pe care le invocă (fără să le citeze propriu-zis) sunt edificate într-un plan superior de integrare teoretică, ceea ce îl transformă pe Blaga într-un filozof (sau estetician) al contradicțiilor integrate. 


\section{Bibliografie:}

Blaga, Lucian, Filozofia stilului, București, Editura Cultura Națională, 1924.

Blaga, Lucian, Opere, vol. VIII, Trilogia cunoașterii, ediție îngrijită de Dorli Blaga, studiu introductiv de Al. Tănase, București, Editura Minerva, 1983.

Blaga, Lucian, Opere, vol. IX, Trilogia culturii, ediție îngrijită de Dorli Blaga, studiu introductiv de Al. Tănase, București, Editura Minerva, 1985.

Blaga, Lucian, Opere, vol. X, Trilogia valorilor, ediție îngrijită de Dorli Blaga, studiu introductiv de Al. Tănase, București, Editura Minerva, 1987.

Crohmălniceanu, Ovid S., Lucian Blaga, București, Editura pentru Literatură, 1963.

Demetrescu, Ruxandra, „Alois Riegl și întemeierea disciplinei autonome a științei artei” (prefață), în Alois Riegl, Istoria artei ca istorie a stilurilor, antologie, traducere și prefață de Ruxandra Demetrescu, București, Editura Meridiane, 1998.

Ion Ianoși, „Antinomiile unui nordic” (prefaţă), în Wilhelm Worringer, Abstracție și intropatie și alte studii de istoria artei, traducere de Bucur Stănescu, prefață de Ion Ianoși, București, Editura Univers, 1970.

Jones, Michael S., Metafizica religiei. Lucian Blaga și filosofia contemporană, traducere de Geo Savulescu și Dominic Georgescu, București, Editura Self Publishing, 2014.

Micu, Dumitru, Estetica lui Lucian Blaga, București, Editura Științifică, 1970.

Moraru, Cornel-Florin, Atitudinea estetică în filosofia artei. Aplicații asupra esteticii lui Lucian Blaga și Maurice Merleau-Ponty, Iași, Editura Institutul European, 2018.

Pavel, Ioana, „Arta și filozofia barocă în gândirea estetică a lui Lucian Blaga”, în Caietele „Lucian Blaga”, vol. al XIX-lea, Sibiu, Editura Universității „Lucian Blaga”, 2018.

Riegl, Alois, Istoria artei ca istorie a stilurilor, antologie, traducere și prefață de Ruxandra Demetrescu, București, Editura Meridiane, 1998.

Worringer, Wilhelm, Abstracție și intropatie și alte studii de istoria artei, prefață de Ion Ianoși, traducere de Bucur Stănescu, București, Editura Univers, 1970. 